\title{
PENGARUH SENAM POCO-POCO TERHADAP KADAR TRIGLISERIDA DARAH
}

\author{
Chytra Rachmat \\ Shane H.R. Ticoalu \\ Djon Wongkar
}

\author{
${ }^{1}$ Kandidat Skripsi Fakultas Kedokteran Universitas Sam Ratulangi \\ Bagian Anatomi-Histologi Fakultas Kedokteran Universitas Sam Ratulangi Manado \\ Email: chytrarachmat@gmail.com
}

\begin{abstract}
A common form of dyslipidemia is often associated with cardiovascular disease which is hypertriglyceridemia. Triglycerides in the body is mainly used as energy storage for a variety of metabolic processes. Poco-poco gymnastics from North Sulawesi. The purpose of this study is to find out the influence of poco-poco gymnastics to triglyceride blood levels. Methods: This study is experimental using one group pre and post test design, the subjects were 25 female students year 2013 Science and Mathematic Faculty of Pharmacyof Sam Ratulangi University Manado who met the inclusion criterias. Data was analyzed using paired $t$ test. Results: Based on the research that has done from 25 subjects it was obtained that there was a decrease in mean triglyceride levels before and after poco-poco gymnastics for four weeks. However, this decrease was not significant $(\mathrm{p}=0,366)$. Conclusion: There was a decrease in triglyceride levels after poco-poco exercises for four weeks but this is not significant.
\end{abstract}

Keywords : poco-poco gymnastics, triglyceride

\begin{abstract}
Abstrak: Bentuk umum dislipidemia yang sering dikaitkan dengan penyakit kardiovaskuler yaitu hipertrigliseridemia. Trigliserida dalam tubuh terutama dipakai untuk menyediakan energi berbagai proses metabolik. Salah satu faktor yang dapat mempengaruhi kadar trigliserida yaitu olahraga. Senam poco-poco merupakan senam yang berasal dari Sulawesi Utara. Penelitian ini bertujuan untuk mengetahui pengaruh senam poco-poco terhadap kadar trigliserida darah. Metode: Penelitian ini bersifat eksperimental dengan rancangan one group pre and post test dengan jumlah subjek penelitian 25 mahasiswi Program Studi Farmasi Fakultas MIPA Universitas Sam Ratulangi Manado yang memenuhi kriteria. Data dianalisis dengan uji t berpasangan. Hasil: Berdasarkan penelitian yang dilakukan pada 25 subjek penelitian diperoleh hasil yaitu terjadi penurunan rata-rata kadar trigliserida sebelum dan sesudah senam poco-poco selama empat minggu. Namun penurunan ini secara statistik tidak bermakna $(p=0,366)$. Simpulan: Terjadi penurunan kadar trigliserida setelah latihan senam poco-poco selama empat minggu namun penurunan ini secara statistik tidak bermakna.
\end{abstract}

Kata Kunci: senam poco-poco, trigliserida

Aktivitas fisik memberikan banyak manfaat bagi tubuh manusia, contohnya aktivitas fisik dapat menurunkan tekanan darah dan kadar trigliserida plasma serta dapat meningkatkan kadar kolesterol HDL (high density lipoprotein) plasma. Tekanan darah tinggi merupakan risiko utama stroke sedangkan tingginya kadar trigliserida plasma dan rendahnya kadar HDL diasosiasikan dengan aterosklerosis dan peningkatan risiko penyakit jantung. Secara umum, olahraga dapat menurunkan risiko kematian atau 
kesakitan akibat berbagai penyakit kardiovaskuler. $^{1}$

Salah satu aset budaya yang dimiliki Sulawesi Utara yang digolongkan sebagai aktivitas fisik yaitu senam poco-poco. ${ }^{2}$

Banyaknya fasilitas yang memudahkan seseorang melakukan kerja seperti motor dan eskalator serta jenis aktivitas tertentu seperti mahasiswa, dosen atau karyawan kantoran yang menuntut seseorang untuk lebih banyak duduk atau bekerja di depan komputer menyebabkan kurangnya aktvitas fisik dan waktu untuk berolahraga.

Menurut data WHO (World Health Organization), penyakit tidak menular (PTM) membunuh lebih dari 38 juta orang setiap tahun. Sebagian besar kematian karena penyakit tidak menular disebabkan oleh penyakit kardiovaskular yaitu 17,5 juta. Ada empat faktor risiko yang berhubungan dengan keadaan tersebut yaitu perokok, kurangnya aktivitas fisik, alkohol dan diet yang tidak sehat. $^{3}$ Di Indonesia prevalensi penyakit jantung koroner yang terdiagnosis oleh dokter tertinggi di Sulawesi Tengah 0,8\% diikuti Sulawesi Utara, DKI Jakarta dan Aceh masing-masing 0,7\%. ${ }^{4}$

Dislipidemia adalah kelainan metabolisme lipid yang ditandai dengan peningkatan maupun penurunan fraksi lipid dalam plasma. Kelainan fraksi lipid yang utama adalah kenaikan kadar kolesterol (kolesterol total), kolesterol low density lipoprotein (kolesterol LDL), trigliserida serta penurunan kadar kolesterol high density liporpotein (kolesterol HDL). ${ }^{5}$ Bentuk umum dislipidemia yang sering dikaitkan dengan penyakit kardiovaskuler yaitu hipertrigliseridemia. ${ }^{6} \quad$ Trigliserida dibentuk di hati dari gliserol dan asam lemak dalam makanan atau dari kelebihan kalori akibat makan berlebihan. Trigliserida dalam tubuh terutama dipakai untuk menyediakan energi berbagai proses metabolik. Kelebihan trigliserida akan disimpan di jaringan adiposa sebagai cadangan energi. ${ }^{7}$ The National
Cholesterol Education Program Adult Treatment Panel's third report (ATP III) menegaskan bahwa peningkatan trigliserida terutama berhubungan dengan penurunan kadar kolesterol HDL. Kondisi ini merupakan bagian dari sindroma metabolik. ${ }^{8}$ High Density Lipoprotein (HDL) yang bersifat protektif, berfungsi untuk membawa lemak ke hepar dan menghambat oksidasi LDL dan molekul adhesi, sehingga menghambat pembentukan sel busa dan pada akhirnya menghambat progresifitas aterosklerosis. Pasien dengan sidroma metabolik (kriteria NCEP ATP III) mempunyai peningkatan risiko terjadinya penyakit kardiovaskular dengan relative risk 1,65 oleh karena itu pedoman utama pencegahan penyakit kardiovaskular terbaru menghimbau identifikasi pasien dengan sindroma metabolik agar dapat melakukan intervensi lebih awal. ${ }^{9}$

Terbukti aktivitas fisik dapat menurunkan kadar trigliserida, pada beberapa penelitian sebelumnya. ${ }^{10}$

Berdasarkan uraian di atas maka peneliti tertarik untuk melakukan penelitian tentang pengaruh senam pocopoco terhadap kadar trigliserida.

\section{METODE PENELITIAN}

Jenis penelitian yang digunakan dalam penelitian ini ialah penelitian eksperimen dengan rancanganone group pre and posttest yang dilaksanakan di Aula Kampus Kleak dan Laboratorium Klinik Patra selama bulan Oktober sampai dengan Desember 2014.

Sampel penelitian yang digunakan ialah Mahasiswa Fakultas MIPA Program Studi Farmasi Universitas Sam Ratulangi Manado Angkatan 2013 yang berjumlah 25 orang yang dipilih secara purposive sample dengan memenuhi kriteria inklusi, yaitu IMT normal $\left(18,5-25,9 \mathrm{~kg} / \mathrm{m}^{2}\right)$, serta kriteria eksklusi, yaitu perokok aktif, menjalani program diet tinggi lemak, riwayat mengalami gangguan muskuloskeletal, menggunakan obat statin dansedang melakukan aktivitas olahraga rutin. 
Variabel bebas ialah senam pocopoco, sedangkan variabel terikat ialah kadar trigliserida darah. Senam pocopoco dilakukan sebanyak tiga kali dalam seminggu selama empat minggu dengan durasi selama 45 menit. Kadar trigliserida darah diukur pada pagi hari sebelum melakukan senam poco-poco pertama kali (pretest) dan satu hari (besok paginya) setelah melakukan senam pocopoco terakhir kali (posttest) dengan terlebih dahulu dipuasakan selama 8-12 jam.

\section{HASIL PENELITIAN}

Deskripsi karakteristik sampel penelitian berdasarkan usia dapat dilihat pada tabel 1 .

Tabel 1. Distribusi sampel penelitian berdasarkan usia

\begin{tabular}{ccc}
\hline Usia & Frekuensi & $\%$ \\
\hline 18 & 18 & 72,0 \\
19 & 6 & 24,0 \\
20 & 1 & 4,0 \\
Total & 25 & 100,0 \\
\hline
\end{tabular}

Deskripsi karakteristik sampel penelitian berdasarkan tinggi badan dapat dilihat pada tabel 2.

Tabel 2. Deskripsi sampel penelitian berdasarkan tinggi badan

\begin{tabular}{lc}
\hline \multicolumn{1}{c}{ Klasifikasi } & $\begin{array}{c}\text { Tinggi Badan } \\
(\mathrm{cm})\end{array}$ \\
\hline Rata-rata & 154,224 \\
Standar Deviasi & 4,6277 \\
Nilai Minimum & 146,7 \\
Nilai Maksimum & 169,1 \\
\hline
\end{tabular}

Deskripsi karakteristik sampel penelitian berdasarkan berat badan dapat dilihat pada tabel 3.

Tabel 3. Deskripsi sampel penelitian berdasarkan berat badan

\begin{tabular}{lcc}
\hline \multirow{4}{*}{ Klasifikasi } & Berat & Berat \\
& Badan & Badan \\
& Pre Test & Post test \\
$(\mathrm{Kg})$ & $(\mathrm{Kg})$ \\
\hline Rata-rata & 52,100 & 51,408
\end{tabular}

\begin{tabular}{lcc} 
Standar Deviasi & 6,1084 & 5,8412 \\
Nilai Minimum & 43,5 & 42,0 \\
Nilai Maksimum & 74,0 & 71,5 \\
\hline
\end{tabular}

Deskripsi karakteristik sampel penelitian berdasarkan indeks massa tubuh (IMT) dapat dilihat pada tabel 4.

Tabel 4. Deskripsi sampel penelitian berdasarkan IMT

\begin{tabular}{lcc}
\hline \multicolumn{1}{c}{ Klasifikasi } & $\begin{array}{c}\text { IMT } \\
\text { Pre Test } \\
\left(\mathrm{Kg} / \mathrm{m}^{2}\right)\end{array}$ & $\begin{array}{c}\text { IMT } \\
\text { Post Test } \\
\left(\mathrm{Kg} / \mathrm{m}^{2}\right)\end{array}$ \\
\hline Rata-rata & 21,8732 & 21,5860 \\
Standar Deviasi & 1,92157 & 1,87260 \\
Nilai Minimum & 18,63 & 18,25 \\
Nilai Maksimum & 25,88 & 25,17 \\
\hline
\end{tabular}

Deskripsi karakteristik sampel penelitian berdasarkan kadar trigliserida darah dapat dilihat pada tabel 5.

Tabel 5. Deskripsi berdasarkan kadar trigliserida darah

\begin{tabular}{lcc}
\hline Klasifikasi & $\begin{array}{c}\text { Trigliserida } \\
\text { Pre Test } \\
\text { (mg/dl) }\end{array}$ & $\begin{array}{c}\text { Trigliserida } \\
\text { Post Test } \\
\text { (mg/dl) }\end{array}$ \\
\hline $\begin{array}{l}\text { Rata-rata } \\
\text { Standar }\end{array}$ & 58,08 & 55,44 \\
$\begin{array}{l}\text { Deviasi } \\
\text { Nilai }\end{array}$ & 15,245 & 14,207 \\
Minimum & 34 & 30 \\
$\begin{array}{l}\text { Nilai } \\
\text { Maksimum }\end{array}$ & 91 & 85 \\
\hline
\end{tabular}

Hasil analisis terhadap kadar trigliserida darah menggunakan uji Paired T-Test (uji t berpasangan) dengan interval kepercayaan 95\% ditampilkan pada tabel 6 .

Tabel 6. Analisis terhadap kadar trigliserida darah

\begin{tabular}{lcc}
\hline & Keputusan & $\begin{array}{c}p \text {-value } \\
\text { (Nilai } \mathrm{p})\end{array}$ \\
\hline $\begin{array}{l}\text { Kadar Trigliserida } \\
\text { Darah }\end{array}$ & $\mathrm{H}_{1}$ ditolak & $0,366^{*}$ \\
\hline *tidak bermakna $(\mathrm{p}>0,05)$ & \\
BAHASAN &
\end{tabular}

Kadar trigliserida rata-rata sebelum latihan 58,08 $\mathrm{mg} / \mathrm{dl}$ dengan nilai 
minimum $34 \mathrm{mg} / \mathrm{dl}$ dan nilai maksimum $91 \mathrm{mg} / \mathrm{dl}$. Kadar trigliserida setelah latihan rata-rata 55,44 mg/dl dengan nilai minimum $30 \mathrm{mg} / \mathrm{dl}$ dan nilai maksimum $85 \mathrm{mg} / \mathrm{dl}$. Selisih kadar trigliserida sebelum latihan senam poco-poco dan sesudah latihan senam poco-poco yaitu 2,64 mg/dl. Kadar trigliserida normal yaitu 30-150 mg/dl. Dapat dilihat pada nilai maksimum dan minumum kadar trigliserida sebelum dan setelah latihan senam poco-poco selama empat minggu berada dalam batas normal, walaupun demikian masih terdapat sedikit penurunan pada nilai maksimum dan minimum setelah melakukan senam poco-poco selama empat minggu.

Hasil analisis pada penelitian ini secara statistik tidak terjadi penurunan kadar trigliserida sesudah latihan senam poco-poco selama empat minggu. Berbeda dengan penelitian yang dilakukan oleh Sondakh yang menunjukkan adanya penurunan kadar trigliserida setelah melakukan senam bugar lansia secara rutin tiga kali seminggu selama empat minggu. ${ }^{10}$

Terdapat penurunan rata-rata kadar trigliserida setelah latihan poco-poco selama empat minggu namun penurunan ini secara statistik tidak signifikan. Hal ini mungkin disebabkan karena program latihan poco-poco belum mampu mengendalikan kadar trigliserida darah, baik karena durasi maupun intensitasnya. Serupa dengan penelitian ini penelitian yang dilakukan oleh Defia yang menyatakan tidak ada perubahan kadar trigliserida darah setelah latihan senam poco-poco tiga kali seminggu selama empat minggu, ${ }^{11}$ serta penelitian yang dilakukan oleh Murbawani yang melakukansenam jantung sehat satu kali per minggu dengan tiga kali perminggu. Penelitian lain menyebutkan bahwa latihan dengan intensitas rendah tidak akan mampu memberikan perubahan pada profil lemak. Pengeluaran energi tidak akan maksimal pada olahraga dengan intensitas rendah sehingga tidak akan mempengaruhi kadar profil lemak dalam tubuh seseorang. Pengurangan trigliserida yang signifikan terjadi pada pengeluaran energi latihan 1000-1200 $\mathrm{kkal} /$ minggu, namun pengeluaran energi ini tidak konsisten menurunkan kadar trigliserida. ${ }^{12,13}$ Pada penelitian ini tidak dilakukan pengukuran denyut nadi sehingga intensitas latihan tidak dapat diketahui.

Selain itu faktor lain yang dapat mempengaruhi hasil penelitian ini yaitu asupan kolesterol pada sampel penelitian. Penelitian yang dilakukan oleh Roux dkk menyebutkan bahwa asupan kolesterol yang tinggi mempengaruhi kadar trigliserida, LDL dan HDL darah. Meningkatnya asupan kolesterol dari batas normal yaitu $200 \mathrm{mg} / \mathrm{hari}$ menjadi 400-500 mg/hari meningkatkan kadar trigliserida 5-10 mg/dL. ${ }^{12,14}$ Penelitian lain yang dilakukan oleh Al-Zahrani yang meneliti tentang pengaruh kontrol diet dan latihan pada profil lipid pada pasien obes. Dari hasil penelitian Al-Zahrani didapatkan bahwa subjek yang melakukan kontrol diet dan latihan selama 60 hari lebih bermakna menurunkan atau menormalkan kadar lipid profil dari pada subjek yang hanya melakukan kontrol diet atau latihan saja. ${ }^{15}$ Dalam penelitian ini tidak dilakukan kontrol terhadap asupan kolesterol pada subjek penelitian sehingga tidak dapat diketahui dengan pasti jumlah asupan kolesterol subjek penelitian selama latihan.

\section{SIMPULAN}

Tidak ada perubahan bermakna kadar trigliserida darah Mahasiswi Fakultas MIPA Program Studi Farmasi Universitas Sam Ratulangi Manado Angkatan 2013 setelah melakukan senam poco-poco selama empat minggu.

\section{SARAN}

Perlu dilakukan penelitian lebih lanjut mengenai pengaruh senam pocopoco terhadaap kadar trigliserida pada jumlah sampel yang lebih besar, waktu penelitian yang lebih panjang, dengan 
metode pengendalian faktor yang berpengaruh terhadap kadar trigliserida yang lebih ketat serta pada populasi dan karakteristik subjek penelitian yang lainnya

\section{UCAPAN TERIMA KASIH}

Ucapan terima kasih disampaikan kepada dr. Shane H. R. Ticoalu, M.Kes, AIFO dan dr. Djon Wongkar, M.Kes, AIFO selaku dosen pembimbing penulis, serta kepada DR. dr. Taufiq F. Pasiak, M.Kes, MPdI dan dr. S.J.R. Kalangi, Mbiomed, PA selaku dosen penguji penulis. Selain itu juga, kepada semua pihak, baik secara langsung maupun tidak langsung, yang telah menambahkan ide dan gagasan bagi penulis sehingga dapat menyelesaikan artikel ini.

\section{DAFTAR PUSTAKA}

1. Silverthorn DU. Fisiologi manusia. Edisi ke-6. Jakarta: EGC; 2014.h.878-9.

2. Rattu AJ, Rampengan JJ. Perubahan Kadar High Density-Lipoprotein Setelah Senam Poco-poco [serial online]. Buletin Penelitian Kesehatan. 2004;32:43-8. Tersedia:

http://ejournal.litbang.depkes.go.i d/index.php/BPK/article/view/170

3. World Health Organization. Noncommunicable diseases. 2013 Maret [diakses tanggal : 5 februari 2015]. Tersediadari http://www.who.int/mediacentre/fact sheets/fs355/en/

4. Badan Penelitian dan Pengembangan Kesehatan Kementerian Kesehatan RI. Riset kesehatan dasar 2013. 2013. h. 91

5. Soebroto L. Hubungan antara kadar LDL kolesterol pada penderita stroke di Rumah Sakit Dr. Moewardi Surakarta. Surakarta: Universitas Sebelas Maret. 2010. Tersedia: http://eprints.uns.ac.id/176/1/166060 109201010431.pdf

6. Baiduri I. Pengaruh pemberian yoghurt kedelai hitam (black soyghurt) terhadap kadar trigliserida serum pada tikus hipertrigliseridemia.

Semarang. Universitas

Diponegoro.201. Tersedia:

http://eprints.undip.ac.id/35871/1/40

9_Intan_Baiduri_G2C007039.pdf

7. Guyton AC, Hall JE. Buku Ajar Fisiologi Kedokteran. Edisi Ke-11. Irawati, Ramadhani D, Indriyani F, Dany F, Nuryanto I, Rianti SS, dkk, alih bahasa. Jakarta: EGC Medical Publisher; 2008. h. 882-93.

8. Mustikaningrum S. Perbedaan kadar trigliserida darah pada perokok dan bukan perokok [serial online]. Surakarta: Universitas Sebelas Maret. $2010 . \quad$ Tersedia: http://eprints.uns.ac.id/5196/1/j.pd $\mathrm{f}$

9. Rohman MS. Patogenesis dan terapi sindroma metabolik. Jurnal Kardiologi Indonesia. Maret 2007:160-8. Tersedia: http://indonesia.digitaljournals.org /index.php/karidn/article/view/453

10. Sondakh $R$, Pangemanan $D$, Marunduh S. Pengaruh senam bugar lansia terhadap kadar trigliserida darah. Jurnal eBiomedik. Maret 2013.h.775-9. Tersedia:

http://download.portalgaruda.org/ article.php?article $=157422 \&$ val $=1$ 008\&title=PENGARUH\%20SEN AM\%20BUGAR\%20LANSIA\%2 0TERHADAP\%20KADAR\%20T RIGLISERIDA

11. Roza Defia. Pengaruh latihan fisik terhadap profil lipid wanita usia dewasa. MNM. 2010.29-35. Tersedia:file://D:/Downloads/Jur nal\%20DefiaRoza\%20(1).pdf

12. Murbawani EA, Darmono SS, Subagyo HW. Perbedaan profil lipid pada peserta senam jantung sehat. Jurnal Gizi Indonesia. 2006.h.26-33.Tersedia: http://ejournal.undip.ac.id/index.p hp/jgi/article/view/3242

13. Dsurstine J.L, et al. Blood lipid and lipoprotein adaptations to exercise. Sport Med. 2001.1033- 
62.

Tersedia:

106.

Tersedia

http://www.iub.edu/ k662/articles

http://www.nejm.org/doi/pdf/10.1

/lipid/ex\%20review\%20Durstine

\%202001.pdf

056/NEJM200107123450205

15. Al-Zahrani SS. Effect of diet control and exercise on the lipid profile of obese men [serial online]. Int J Res Med Sci. 2014;95-99.

residence and incidence of coronary heart disease [serial online]. N Engl J Med. 2001.99- 